\title{
SMART LOCKDOWN STRATEGY, SECOND AND THIRD WAVES OF COVID-19 IN PAKISTAN: A POLITICAL DISCOURSE ANALYSIS \\ Hanan Afzal ${ }^{1}$, Masroor Sibtain ${ }^{2 *}$, Zafar Iqbal ${ }^{3}$, Hina Saleem ${ }^{4}$ \\ ${ }^{1,4}$ National University of Modern Languages, Islamabad, Pakistan; ${ }^{2}$ Department of English, Government Graduate College of Science, Multan, Pakistan; ${ }^{3}$ Minhaj University, Lahore, Pakistan. \\ Email: "zammad.aslam@gmail.com
}

Article History: Received on $21^{\text {st }}$ March 2021, Revised on $1^{\text {st }}$ June 2021, Published on $13^{\text {th }}$ June 2021

\section{Abstract}

Purpose: The present study investigates the violations of SOPs regarding the spread of COVID19 during the political processional campaigns in the Gilgit Baltistan and Senate elections in Pakistan held just before the second and third waves of COVID-19. For instance, during the first wave Pakistani government employed a smart lockdown along with persuasive awareness campaign. However, in the second and third waves, it seemed that SOPs were not influential due to violations by politicians themselves.

Method: The researchers analyze the journalistic text both verbal and pictorial by employing the qualitative and interpretive paradigm to understand the policies and strategies of political parties in their political gatherings. Data regarding political campaigns have been collected from the print media through the purposive sampling technique. The secondary data has been collected from various research publications to establish the background.

Main Findings: The study analyzed political response to COVID-19 SOPs on the part of Pakistani political parties during the political campaigns in Gilgit Baltistan and senate elections. Referent pictures (see Figures), taken from authentic, official newspaper websites, showed that during 'Political congregations and rallies', individuals and politicians attended the events without requiring social distance and masks. Both the opposition and ruling party and their workers have taken approximately equal parts to violate the SOPs to gain political gains and benefits.

Application of the Study: The study suggests that the political parties would not conduct these types of political events that cause the spread of the virus, especially when it is considered a worldwide pandemic. The study would be both socially and politically beneficial for the organizations and groups to learn how a pandemic may affect the masses if precautionary measures are not followed adequately.

The Originality of the Study: According to the researchers' best knowledge, the research gap of the present study is contemporary and innovative, i.e., integrating the conceptual model of political discourse with political events.

Keywords: COVID-19 SOPs Violations, Political Discourse Analysis, COVID-19 Pandemic, COVID-19 Second and Third Waves Pakistan, Smart Lockdown.

\section{INTRODUCTION}

The present study focuses on the desperate struggle of the state of Pakistan concerning COVID19. Due to multiple reasons ranging from political and economic, the government could not restrain political processional campaigns by the opposition (Inayat, 2020; Nagri, 2020). The main reason for non-implementation of SoPs was the participation of the ruling party itself in the election campaigns. For instance, in September 2020, the provisional provincial elections were held in Gilgit Baltistan (G.B.), and Senate elections were held on March 10, 2021. The ruling party (PTI) and opposition (PDM) enthusiastically participated in both polls. Moreover, the opposition also initiated a movement against the sitting government. The alliance of political parties belonging to PDM left a remarkable impact on the increasing cases of COVID-19. Even the ruling party could not lag, and it also started its political campaigns against the opposition party, especially PDM. Raising political agendas against each other by both sides created a complicated situation for the public. Resultantly, the supporters of each party came out, gathered in processions to favor their party. As the political events succeeded one after another, COVID-19 also went towards a new spike, increasing COVID-19 patients. Nevertheless, surprisingly, no one cared for it, even the government as well. The Prime Minister and his cabinet launched a plan to implement safety measures but practically could not do anything as envisioned.

Consequently, the situation started becoming worse with the passing days to date. They organized all these political activities for their political interests without thinking about the upcoming harmful effects, and this situation is becoming critical day by day. On April 2, 2020, the daily patients were 6000 in number, then it came down to 300 patients on August 19, 2020, daily, but in the third wave on April 2, 2021, this number increased drastically again 5234 daily. Positive cases and daily deaths were going to an alarming situation and out of control. If the government did not take serious steps to get the safety measures implemented in the whole country, and corona cases and deaths increase (Nagri, 2020). On the other hand, the entire world has put off its essential political and social activities to keep people safe from the Pandemic of COVID-19. The study plays a significant role in highlighting the non-serious attitude/behavior of the Pakistani political elite.

Additionally, the study explores the media news reports' insights, which reveal the events and issues criticizing them ironically and humorously in written/pictorial language (Martin and Nakayama, 2010). Nowadays, the Pandemic of 
COVID-19 has destroyed the world (Iqbal et al., 2020), and its second and third waves are considered more dangerous by the experts (WHO, 2020; Ogen, 2020). However, Pakistani politicians, including the opposition and government, seemed to ignore the SOPs and precautionary measures regarding the country's safety against this Pandemic (Sahin et al., 2020). Although the vaccine against COVID19 is developed, most parts of the world are still devoid of it; specifically, Pakistan faces the absence or lack of a vaccine (Ashfaq and Bashir, 2021). So, the best cure is to follow the precautions followed in other viral diseases (Malay, 2020), i.e., Dengue, Ebola, or SARS. During the first wave of COVID-19, the Government of Pakistan implemented a smart lockdown concerning COVID19 (Iqbal et al., 2020). The World Health Organization appreciated the particular and genius approach of worldwide smart lockdown (ibid). After the above-mentioned political campaigns, the COVID-19 cases and casualties are going to assume an extreme position. Figure 1 explains the Covid circumstances from February 7, 2020, to May 21, 2021, taken from Pakistan's official portal.



Figure 1: COVID-19 History in Pakistan

Source: $\underline{\text { https://covid.gov.pk/stats/pakistan }}$

The COVID-19 is an abbreviation of 'Coronavirus Disease spread first time in December 2019' (WHO, 2020); it retains numerous symptoms, for instance, fever, lung infection, pneumonia, flu, respiratory issues, and cough (qㅏbal et al., 2020; Hani et al., 2020; WMHC, 2020). Meanwhile, coronavirus was usually found in birds and animals worldwide (Rahman et al., 2020; Zhuang et al., 2020), yet there were rare cases in human beings till December 2019 (Iqbal et al., 2020). For instance, Li et al. (2020) and Iqbal et al. (2020) stated that in December 2019, COVID-19 affected the breathing tract of patients with pneumonia in the city of Wuhan, a city of China (WHO, 2020; Li et al., 2020; Wu et al., 2020). The virus, which is mainly presented in humans and other mammals, belongs to the family of Coronaviridae and the order Nidovirales enclosed in a non-segmented positive-sense RNA virus (Zhao et al., 2020). Furthermore, this virus's common symptoms and signs are dyspnea, dry cough, bilateral lung infiltrates on imaging, and fever (Ksiazek et al., 2003).

Moreover, the virus spread quickly and immediately after being reported on a few cases in Wuhan within one month (January 2020 to February 2020). With time, the coronavirus cases have been reported in thousands, and more than two thousand died in China only (WHO, 2020a; Iqbal et al., 2020). When most developing countries were fighting against the coronavirus disease, Pakistan was on the upsetting verge. Since the first case of COVID-19, reported in the big city of Karachi (Sahin et al., 2020), the number of cases reported in Pakistan till June 12, 2020, sharply reached one hundred and then fifty thousand, including more than 2000 deaths. In the beginning, medical experts considered it as a kind of flu, yet it is found to be more harmful and damaging than conventional flu (Alimolaie, 2020).

Furthermore, it spreads from one person to another through nasal exhales (sneeze and cough), physical contact, point of contact i. e, handshakes, hugs, and mutual connection of surfaces (WHO, 2020b and Iqbal et al., 2020). In the first wave of COVID-19, Pakistan, through the smart lockdown and Vector Autoregressive model (see Iqbal and Younas, 2021; Khan et al., 2020; for more details), controlled the increasing coronavirus cases and decreased patients from 6604 (see Figure 2) to a few hundred. The efforts made by the Government of Pakistan were appreciated by other countries, especially from the World Health Organization (WHO, 2020), yet; the same govt showed negligence and sluggishness being relaxed. As a result, the pandemic got a chance to spread in the whole country once again. WHO (2020b) endorsed a few precautions to avoid COVID-19; for instance, vaccination and preventive measures could be the last choice in viral viruses? 
Moreover, an uncountable number of years are required to vaccinate the masses. Still, the government does not seem serious, mature, and consciously attentive to import vaccines as per the required quantity. Although we can avoid it by wearing effective face masks, washing hands, face, self-isolation, avoiding crowds, using hand sanitizers, and wearing gloves (before and after performing any human social activity and following the guidelines advised by the medical experts (see Iqbal et al., 2020 for more details),

Moreover, the present study investigates the political, written, and pictorial texts concerning the second and third wave of COVID-19 by employing persuasive strategies (see Norali and Rezaei, 2016; Ting, 2018 for details), especially examining the government's failure in persuasion regarding safety measures in COVID-19. Political discourses are undoubtedly influential venerable political genres (Saeed et al., 2020, Iqbal et al., 2020; Wang and Liu, 2018; Latif, 2016; Ahmad \& Mohammad, 2012). However, sometimes they become less impressive when the leading political actors (authoritative) do not think seriously. The same idea comes true when it is employed in the COVID-19 situation. However, Political Discourse Analysis has often been used as a tool that helps the researchers and audience understand the implicit meanings in the composed text or speech in social and political scenarios (Saeed et al., 2020; van Dijk, 2006).

\section{Objectives}

The present research aims:

- To identify socio-political ideologies) conveyed by print and electronic media (written, graphic, and pictorial text) concerning Pakistani politics within the context of COVID-19.

- To highlight how political campaigns during G.B. and Senate elections by Political parties in Pakistan (specifically PTI and PDM) cause the spread of COVID-19's second \& third waves in Pakistan.

- To highlight the role of persuasion and persuasive strategies used by the political leaders throughout the crisis of COVID-19.

\section{Significance of the Study}

The present research is significant in several aspects, i.e., the study seeks to identify and analyze the activities of political parties during election campaigns which caused more spread of COVID-19 because they violated all the SOPs employed by the Pakistani government. The present research highlights the means and manners of language used in social, electronic, and print media. Additionally, the study highlights specific ideologies) of media and political parties through the language they use, especially by using particular persuasive strategies to argue or justify the spread of COVID-19's $2^{\text {nd }}$ and third wave. These political parties ignored the threats of the fatal disease and continued their political gatherings against each other for their benefit. It seems that they have no care for their public/masses except for their political purposes. On one side, they remained busy in getting their political aims by making speeches to win GB and senate elections, while on the other side, the deadly disease (COVID) kept its fatal attacks and took the lives of the people in thousands.

Hence, the researchers seek the remarkable/significant reasons for the spread of COVID-19, so it is expected that future researchers and students would indicate and arrange adequate policies and impressive strategies to overcome the problems at the policy-making level to control the spread of COVID-19.

\section{THEORETICAL FRAMEWORK}

In this section, the present study reviews the related literature of political texts (written \& pictorial) concerning COVID19 to find and fill the research gap and novelty. Political Discourse Analysis (PDA) is a perspective that is essential to build explicit/surface level and implicit/deep level meanings in the discourse structure, especially in the political and social context (Iqbal et al., 2020; van Dijk, 2018; 2006; 1997b). It describes power, inequality, power relations with language, social practices, abstract considerations, and abuse of power. Additionally, it is a way and approach to convey the desired messages, through language, in a composed structure (written form) of spoken discourse. According to Sharififar \& Rahimi (2015), a language used to communicate with/to other people through oral, written, and spoken text is called discourse.

Moreover, media discourse can be investigated and analyzed in many ways, especially with different goals regarding depiction, setting, or translation of discourses, clarifying why/how it functions in the social and situational context (as cited in Iqbal et al., 2020). Rogers \& Schaenen (2014) state that discourse is the fragment of a language with the practical approach or method that deals with a person's intellect. Iqbal et al. (2020b) argue that discourse analysis (DA) is considered an objective technique of the text (Discourse) structure that is a content of discourse that deals with methods of communication for studying the context of the used language (Sharififar \& Rahimi, 2015). Moreover, political discourse can be divided into social ideology, psychological effects, the individual's perception, and the political context exposed and analyzed by the political discourse analysis (PDA). Henceforth, the text of a language could be fragmented into three parts; language, communication, and interaction (van Dijk, 1997b; Saeed et al., 2020). 
Furthermore, SPDA is functioning at micro and macro levels incorporated at the social and linguistic levels. Wodak (2011) argues that PDA is grounded on cases at the educational level that grasps specific personalities, legislation, philosophies, political issues, convictions, and other belongings recognized with it (Kirvalidze and Samnidize, 2016; Dunmire, 2012). Kirvalidze \& Shanidze (2016) explore that PDA can be shared with various analyses, such as psychological sciences, which appraise philosophy. That is the reason it turned into the most generally utilized technique in the field of present-day linguistics (van Dijk, 2000; Kirvalidze \& Shanidze, 2016; Saeed et al., 2020). Furthermore, it uncovers the power and belief systems having relations in political Discourse (P. D.). According to Xie (2018), Political Discourse Analysis is a tool to analyze discourse that gets thoughts concerning individuals and groups. Fischer and Gottweis (2012) argue that we can interpret the implicit meaning using linguistic and persuasive strategies in the social and situational context (Sarfo \& Krampa, 2013).

In this regard, Wodak and Chilton (2005) remark that politics mainly depends on language, which significantly influences politics. Van Dijk (2005) expresses that thinking is shown and formulated in the discourse. Many researchers have done different types of analysis (see Begum, 2015; Naz et al., 2012; Bughio, 2014; Shahzadi, 2018, etc.) on the speeches delivered by different political leaders such as Nawaz Sharif, Quaid-e-Azam, Benazir Bhutto, Tahir ul Qadri and many others.

van Dijk (1997b) stated that the focus of CDA is on the structures of spoken and written discourse (s), which attempts to uncover linguistic devices being used for the exercise of power in both spoken and written types of address. In this way, CDA helps the masses understand the difference between linguistic tools that explain and those meant for manipulation. The public's ability to comprehend the disguised intentions beyond any discursive act makes them able to cope with the oppressive use of language and create resistance to social injustice and dictatorship (van Dijk, 2000).

We need to know how the power in discourse is displayed when dominant groups of people do so. Furthermore, if they persuade their audience, we need to know about techniques and discursive structures included in the process. CDA is perceived by van Dijk (2006) as analytical research that figures out how inequality, power, and dominance are exercised, produced, and reproduced in written and spoken discourse in various social and political settings (Vulchanova et al., 2019; Hassan, 2018).

\section{Research Gap/Novelty}

The importance of the present study lies in its analysis of written and visual discourse as plays a significant role, especially in applied linguistics (A. L.) and Critical Discourse Analysis (CDA).

Furthermore, the researchers have added various aspects and approaches of (PDA) by uncovering and exploring the jobs of political instruments regarding the development of written, spoken, and visual discourse in specific contexts and settings. It helps the viewers, readers, and listeners enhance their understanding of the social and political ideology/agendas in the written and visual text delivered by the print media. The study also helps normal pursuers scrutinize the Media Discourse (M. D.), which on-screen characters or participants control to drive their political ideologies.

The study makes the researchers ready to further explore M. D. by utilizing distinctive conceptual and theoretical frameworks. At present, the flow of inquiry and examination of the texts (written \& pictorial) uncover the concealed motivation of media discourse. The researchers take the stand to point out the activities of political parties regarding election campaigns that caused the spread of coronavirus (COVID-19) that is increasing day to day due to these political campaigns and gatherings.

Moreover, the researchers employ van Dijk's (1997b) Political Discourse Analysis model to analyze the data. The analysis explores the response Pakistani politicians who continued their political activities and gathered the people at public places (in the shape of the crowd) without considering the precautions (WHO, 2020) during the Pandemic of COVID-19. They only did for the sake of their political benefits and ignored the harmful and dangerous situation of Covid-19. During the first wave of COVID-19, the Government of Pakistan set up rules and regulations (SOPs) regarding precautions to keep the people safe from the pandemic. However, after controlling the rising cases, they forgot their job and could not follow any precautions further. Due to the government's ignorance, the pandemic spreads again at its severe level.

\section{RESEARCH METHODOLOGY}

The researchers analyze the text by employing the qualitative and interpretive paradigm to understand the policies and strategies of political parties in the socio-political realm - the study utilized the data regarding political campaigns from the print media through purposive sampling. The secondary data has been collected from various published research papers to establish the background. The researchers collected primary COVID-19 data from the official online information portal of John Hopkins University. The study used textual and pictorial data from renowned Pakistani news channels' official websites other international news channels, i.e., Golf news, Aljazeera, and YouTube. The researcher aims to use specific tools to analyze and interpret the selected text. For instance, the data has been analyzed employing the conceptual socio-cognitive model of political analysis by van Dijk (1997b). Moreover, the conceptual models for 
rhetorical devices and persuasive strategies have been adapted and modified from Iqbal et al. (2020), Higgin \& Walker (2012) accordingly. All the researchers analyzed the text by employing these devices, sub-devices, and elements.

\section{RESULTS/FINDINGS}

The study investigates the increase of COVID-19 cases due to the congested gathering of the masses during political activities by the opposition and State Government of Pakistan, especially during processional campaigns of the election held in Gilgit Baltistan (a provisional province in Pakistan) and senate elections. The researchers (second and third) previously analyze the persuasive strategies employed by PM Imran Khan to urge the masses for smart lockdown during the first wave. The strategy was considered helpful for the country and appreciated by Pakistan, WHO, IMF, and other international organizations (see Iqbal et al., 2020; Inayat, 2020; WHO, 2020; Gul, 2012; Shah, 2018 for more details). Alternatively, in the second and third waves, the government's policies for preventative measures regarding COVID-19 were also not perceived, even by the government's machinery itself, during the election of Gilgit Baltistan in September 2020. In the next three months, the country bore the spike the COVID19, and Pakistan observed a rise of her second wave, reaching 3795 positive cases on December 6, 2020 (see Figure 2). For instance, they sent their ministers of state to join political campaigns and speeches at public places, and as a result, they gathered thousands of people to show their political power. At that time, the world was facing a Pandemic situation, especially the second wave of COVID-19 (WHO, 2020). Due to this negligence, the opposition got an opportunity and made lame excuses to start political companions (Inayat, 2020). Likewise, the government blames the opposition for spreading the coronavirus due to their gathering to achieve political benefits (Nagri, 2020). For instance, the Prime Minister of Pakistan criticizes the opposition parties by saying that PDM is holding public meetings against the government. They want to hide their illgotten money; he added while repeating his claim that the PDM's campaign is nothing more than a ploy to hide the corruption of its leaders (Inayat, 2020). The comments of PM manifest that his personal stimulus would persuade the public not to join the public meetings. Through tangible stimulus, he tries to prove his views by quoting the doctors' statements that doctors and nurses say that "the burden of patients has increased at hospitals with as many as 70 deaths in a single day" (as cited in Nagri, 2020). He impressively uses visual stimulus by telling the number of deaths due to Corona to make the people abstain from the political processions. However, at the time, his party (PTI) held public meetings to address the masses to favor his candidate. Therefore, the opposition leaders claim that the "Opposition believes the virus is a 'bahana'(excuse) and the real 'nishana' (target) is to squish the mass movement against the PTI government" (Inayat, 2020).

Moreover, from PMLN (opposition), a leader reacted to PM's statement about the dangers of Corona disease by saying: "Please tell me: How intelligent is the coronavirus? Does it only spread at opposition gatherings and stay away from government functions? They are only trying to impose a lockdown on the opposition, but the Pakistani people will impose a lockdown on Imran Khan" (as cited in Siddique, 2020). Her statement in reaction to PM's speech seems impressive and inspiring apparently but seemed political only because she could stop her workers during the spike of COVID, but she did not want to go against her set agendas. Using contrastable stimulus, she criticizes PM because he himself could not follow the precautionary measures that he advised others to follow. PM and his party's failure in following SOPs provided an opportunity for opposition leaders to hold public meetings even though they were fully aware of the deadly effects of COVID. Even they could raise the emotions, using emotional stimulus, of the public, especially their parties' supporters, against the ruling party (PTI).

According to Gulf News (2020), Pakistani political parties were blaming each other regarding the increase of cases of COVID-19 but still gathered the people at public places for their political interests. The political parties did not take any care of the lives of the people of their country as they were not following the preventive measures set by $\mathrm{WHO} /$ government even though the world was following the advised safety measures.

According to Nagri (2020), PM criticizes the opposition by using personal stimuli as some opposition leaders were against the smart lockdown policy of the government. However, the government policy of smart lockdown kept the lives of the masses safe and made the economy of Pakistan stable to some extent otherwise. Then PM blamed the opposition by utilizing the contrastive stimuli, i.e., he mentioned that as compared to the narrative of the opposition leaders, he, in the first wave of COVID19, was not against the smart lockdown and in favor of complete lockdown. Opposition's favor of complete lockdown became suspicious in PM's views as he expressed his idea by saying, “.... During the first wave, the opposition leaders had demanded a complete shutdown. They opposed the government's smart lockdown strategy, which aimed to save the poor from becoming destitute and prevent the economy from total collapse. But now, opposition leaders lacked empathy for the masses as their families had looted national wealth impoverish the people further" (as cited in Raza, 2020). In the statement mentioned above, the primer also uses emotional stimuli to get the favor of the public against his opponents by using empathic words like 'empathy, ' 'poor,' and 'destitute.'

He uses tangible stimulus by clarifying himself as an efficient leading person and his opponents insincere to the masses. According to his perception, his statements would influence the groups, and they would remain from the trappings of the opposition (non-ruling parties). PM creates a contrast between the government and opposition offer services by giving examples of smart lockdown and its advantages. Using emotional stimulus, he tries to show himself as a liberator against the past policies of the previous governments that looted the money of the Pakistani masses and did nothing for their welfare. Therefore, he further seems to use personal stimulus clarifying his ideologies and planning against COVID 
right, proving that smart lockdown can better control the Corona disease instead of complete lockdown. He gets advantages in economic policy-making strategies during COVID-19 when the whole world is suffering from a financial crisis but Pakistan. According to Nagri (2020), the Prime Minister of Pakistan said, "Now, with the new spike, when we again need smart lockdown, they want Jalsas (public gatherings) not caring for the lives and safety of people," the prime minister said in a tweet (as cited in Raza, 2020).

\section{New cases and deaths \\ From JHU CSSE COVID-19 Data · Last updated: 1 day ago}

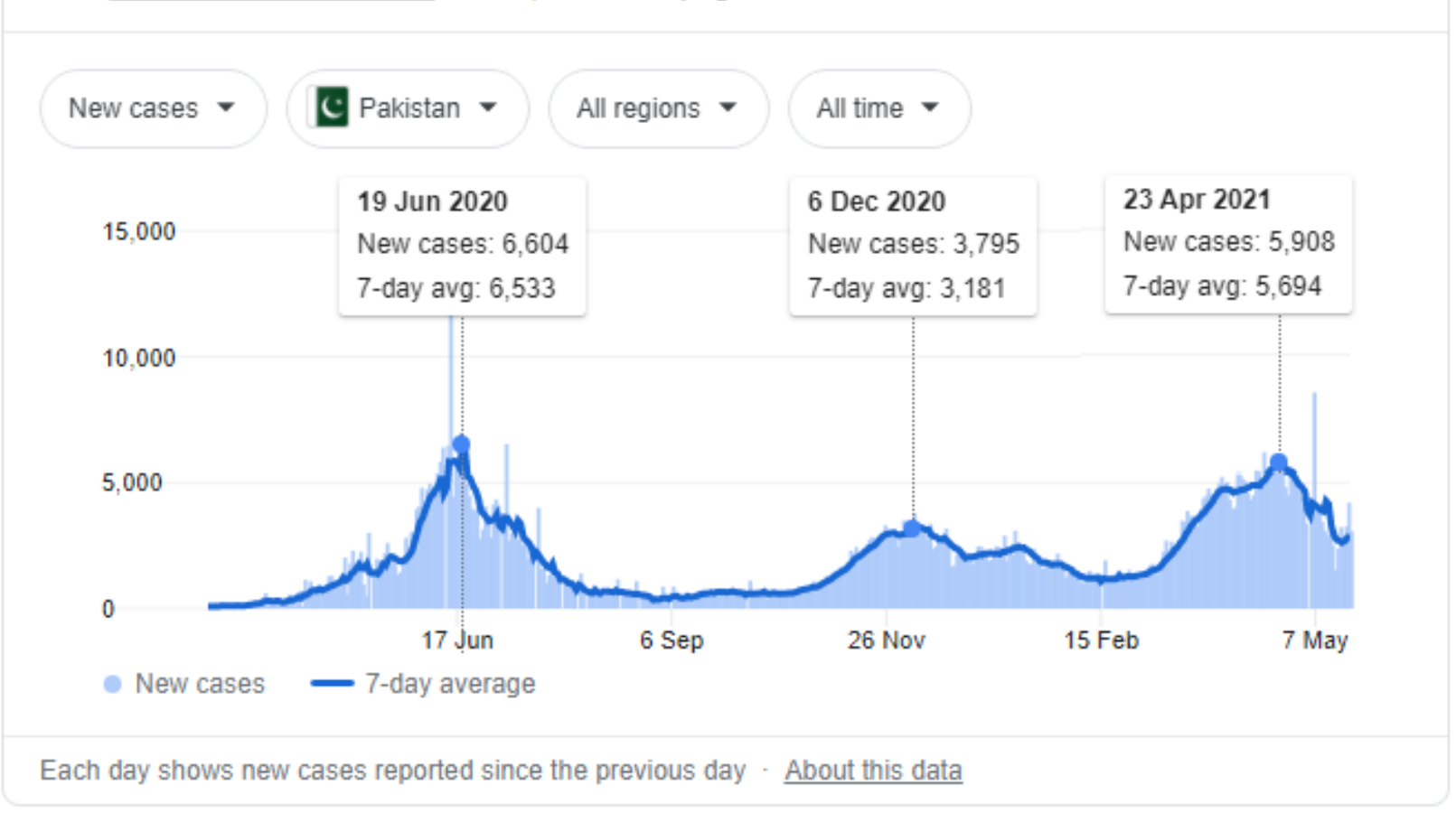

Figure 2: COVID-19 Spikes in Pakistan

\section{Source: https://github.com/CSSEGISandData/COVID-19}

Figure 2 describes the position of COVID-19 cases in the $1^{\text {st }}, 2^{\text {nd, }}$ and third waves. In Pakistan, the first case of COVID19 was reported in March 2020 in Karachi and spread all around Pakistan within two months, and then reached more than 6000 cases per day (see Figure 2). The government of Pakistan controlled the worst situation within a few days. It reduced the cases from 6600 patients per day to 300 patients per day with good governing strategies, i.e., smart lockdown, by the federal and provincial governments, creating awareness of precautions among people to keep the people's life safe. After controlling the cases of COVID-19, they (politicians of Pakistan) did not follow the SOPs of COVID19. Hence, the COVID-19 again started increasing in the third wave due to political activities. Now, the situation seems to become more complicated as people are losing their lives in daily cases. Although about 80 to 130 people die daily, the people do not follow SOPs. Although after reducing to 300 patients daily in the first wave. The cases increased again from 300 to more than 3000 daily in the second wave. Then the number of cases increased again, in the third wave, from 3795 to 5908 on April 23, 2021 (see Figure 2). The people did not seem ready to believe media news about the existence of the deadly disease until they seemed trapped in it (COVID). It is to say with regret that political parties never came to be seen as severe and mature to cope with each other. They just idled and did nothing practically for their masses except political point-scoring and surficial political statements. The opposition seemed pointlessly criticizing government policies and strategies that it made during the spread of the disease. They used media to propagate against the measuring steps against COVID merely to show its (govt) failure in every field of life, especially concerning the control of the pandemic.

Similarly, the govt officials started encountering the statements of the opposition to save their faces. On the other hand, the public faced a dangerous situation in many more patients and daily-based deaths. Nobody seemed to take responsibility for the deaths occurring, even though these were the political gatherings that brought the people's lives. Moreover, it was also a fact that the masses also never care about the danger they were facing or may face in the very, very short. In the first wave, the government got controlled due to the strict SOPs and their practical implementations. The cases increased in the second and third waves due to neglecting and not following the SOPs by the politicians, primarily due to the negligence of political parties. Possibly (politicians) should have been a model in following the SOPs, but unluckily they could not do so, and consequently, the whole nation suffered a lot in COVID. 
Cumulative confirmed COVID-19 cases

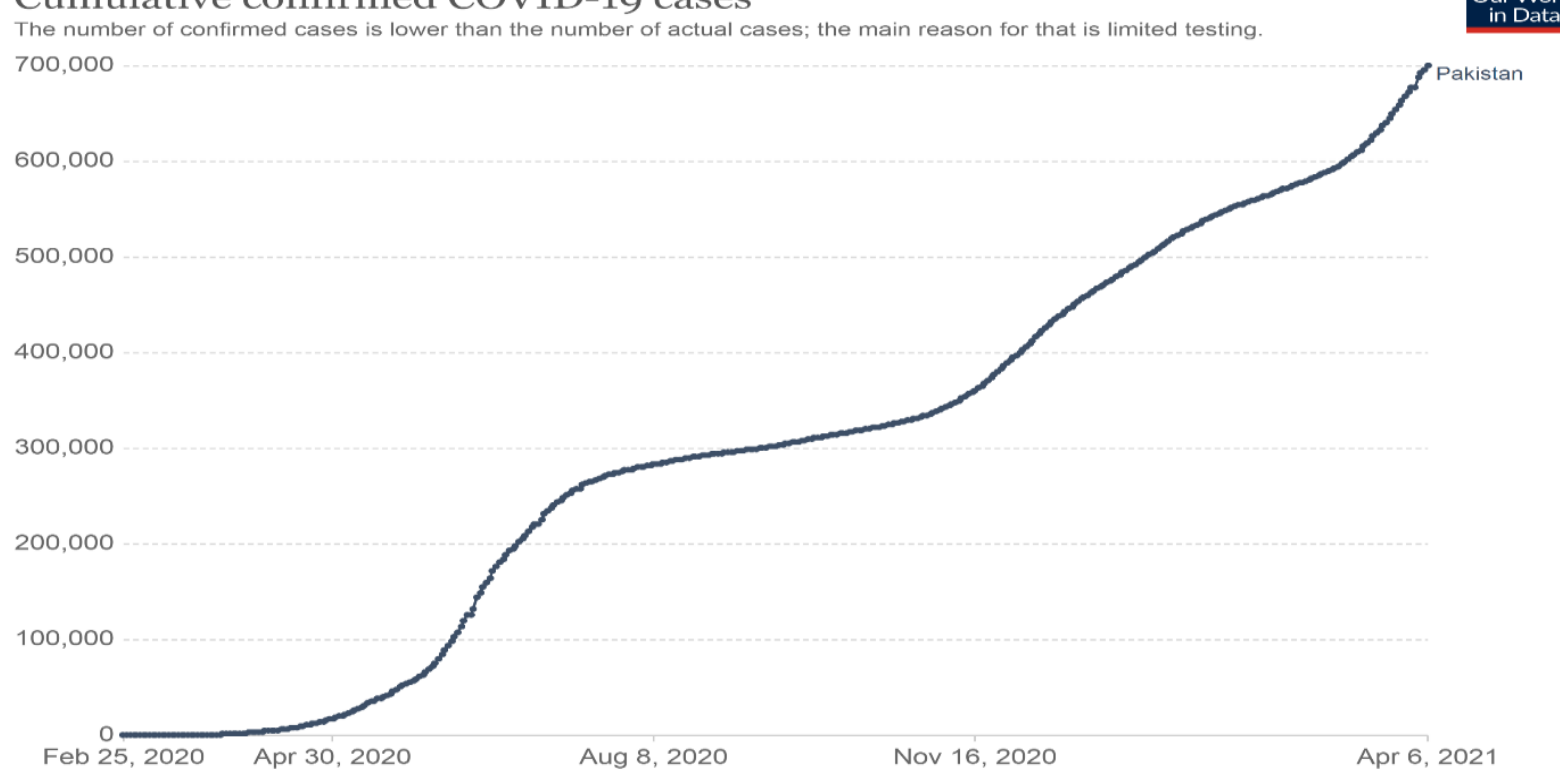

Our World
in Data

Source: Johns Hopkins University CSSE COVID-19 Data

Figure 3: COVID-19 Cumulative confirmed cases in Pakistan

Source: https://coronavirus.jhu.edu/region/pakistan

Figure 3 describes the total cases of COVID-19 in Pakistan from March 2020 to April 2021. In the first wave of this pandemic, the cumulative instances of COVID-19 reached 300000. The COVID-19 went from 300000 to 700000 in the second and third waves. However, conducting tests for COVID-19 diagnoses was very limited in Pakistan due to the shortage of test kits and laboratories. The actual cases were likely to be more than the reported cases in South Asian developing countries such as Pakistan, India, or Afghanistan.

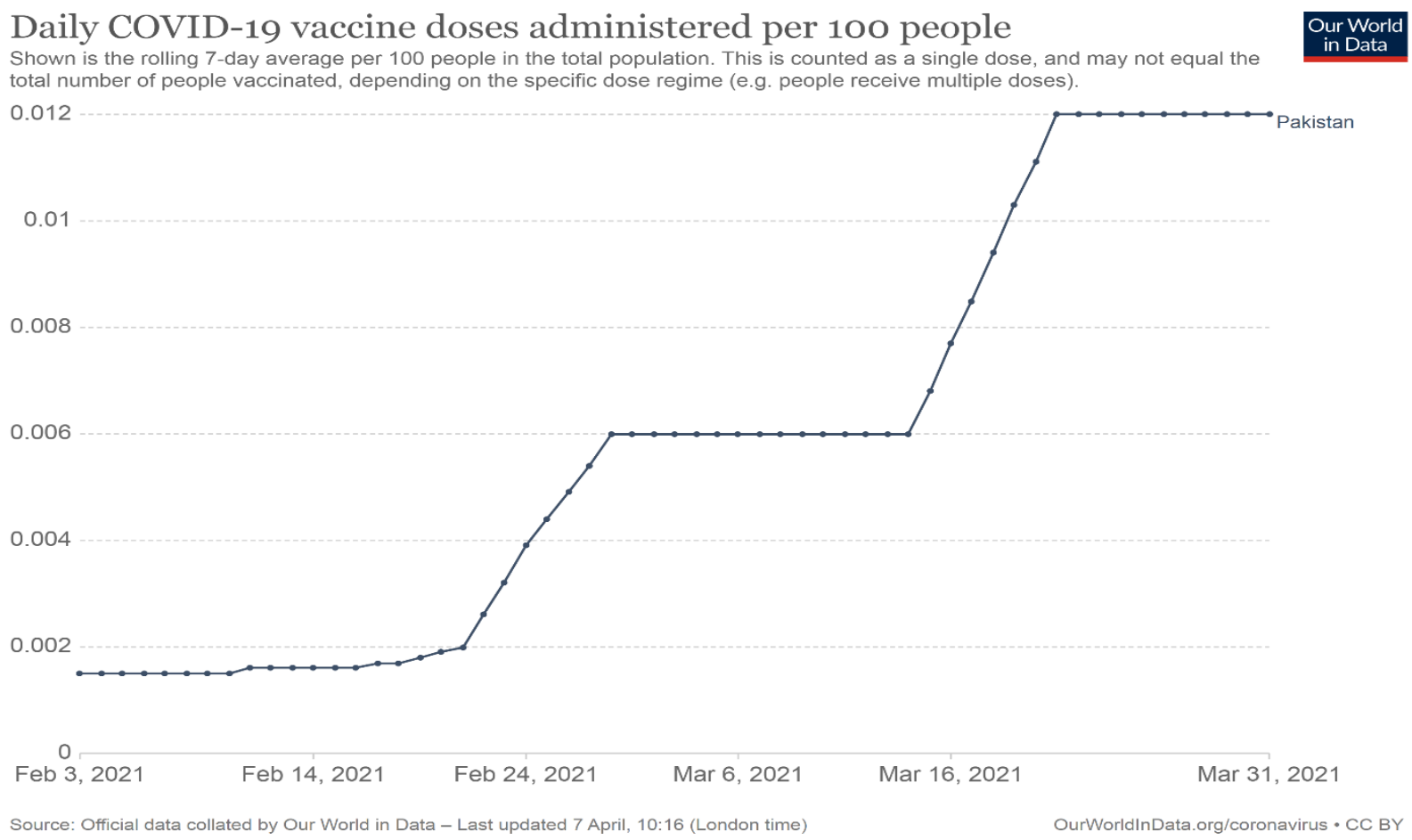

Figure 4: COVID-19 vaccination in Pakistan

Source: https://coronavirus.jhu.edu/region/pakistan

Figure 4 explains the process of vaccination in Pakistan that is very slow compared with the other countries (advanced countries), i.e., Brazil, where more than $50 \%$ of people are vaccinated. But, to date, only 0.010 persons of Pakistan are vaccinated, and the cabinet minister, Asad Umar, says that they require ten years to vaccinate the 22 billion people. 
Therefore, precautions are the only way to keep the masses safe from this pandemic. However, even knowing the consequences, ministers of the government held political processional campaigns during G.B. elections and violated the SOPs that they set for the country's people to make them secure from the pandemic. The opposition also got an excuse from their political activities and started managing and administering the political processions.

For instance, Gulf news (2020) explored that the government warns of severe consequences if PDM rally spreads Novel Coronavirus. The picture below is depicted by the channel mentioned above to portray the PDM leaders' negligence. For example, they gathered the people without taking care of the situation and violating the precautions to keep them away from this virus. For instance, social distance is the only way of protecting the masses from this plow ( $\underline{\mathrm{WHO}, 2020}$; Iqbal et al., 2020).

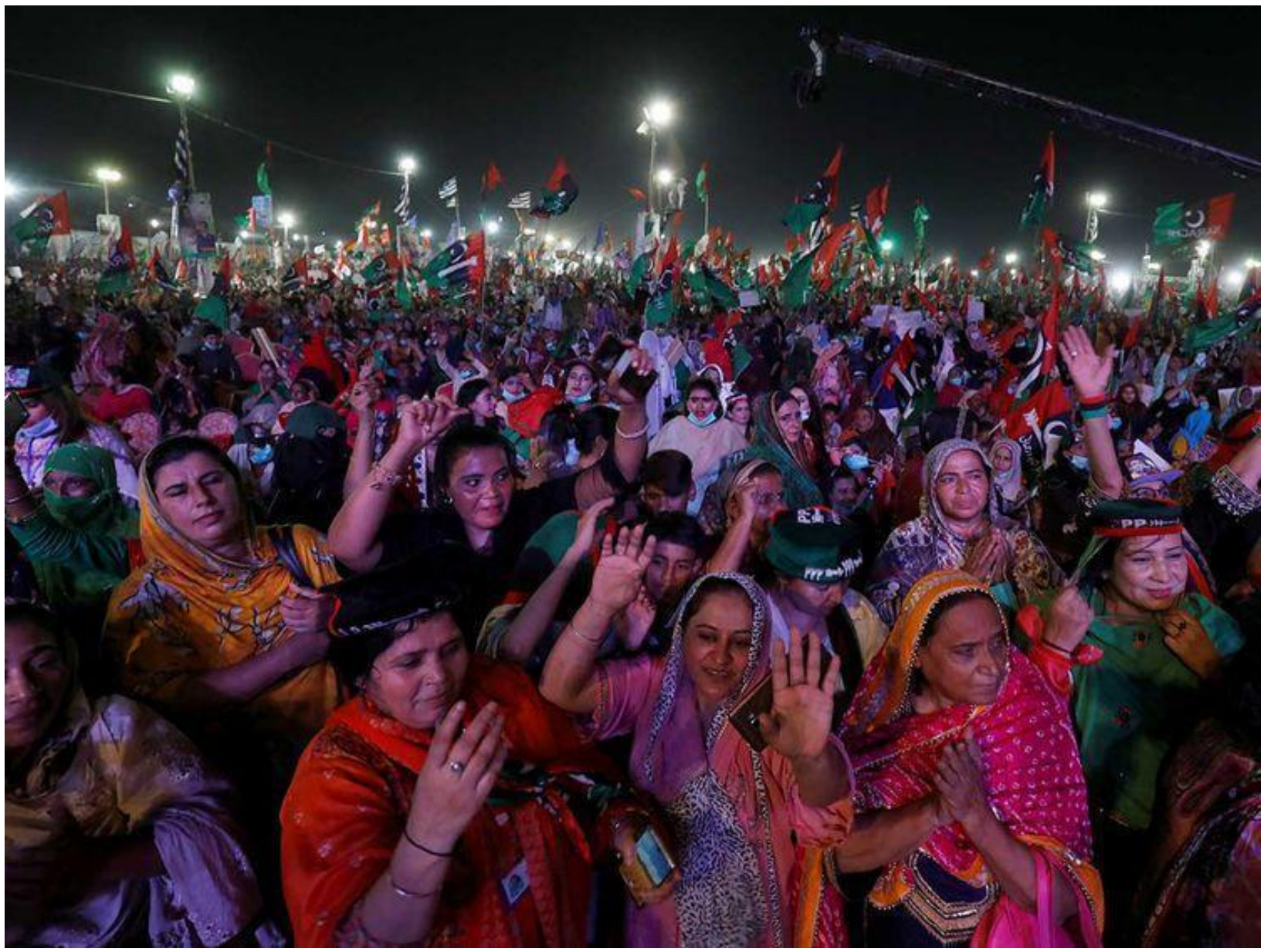

Figure 5: Gathering of people at PDM's political processions against government

Source: https://imagevars.gulfnews.com/2020/10/23/PDM-pakistan-opposition-rally-Karachi_17555cdd5a5_large.jpg

The purpose behind the alliance and movement of PDM was to give a tough time to the ruling party (PTI). Nevertheless, PDM dangerously gathered the people at public places for their political benefits and ignored all necessary preventive measures, i.e., without masks and social distance (see Figure 5). For instance, in the picture mentioned above, people were gathered wearing clothes, caps, and flags of different political parties in PDM's processions. The State government of Pakistan claimed that PDM caused the spread of coronavirus in Pakistan. However, the leading politicians of PDM gave the logic that Ministers of Government. They gathered the people without caring about the separation of COVID19. So, they, the Government and PDM, ignored the severeness just for their political benefits.

It was also evident that the ruling government celebrated their victory without following the COVID-19 SOPs; the people who attended the celebration event sit side-by-side without any social distance and masks (see Figure 7). It was merely a little evidence; both the political parties (ruling \& opposition) had done nothing practically to keep following SOPs and safety measures but raising so-called slogans of protection. Even the government party could not take any action against the persons who violated law and order primarily related to SOPs for COVID. It showed that their primary concern was to push their opposing parties back compared to their other motto. 


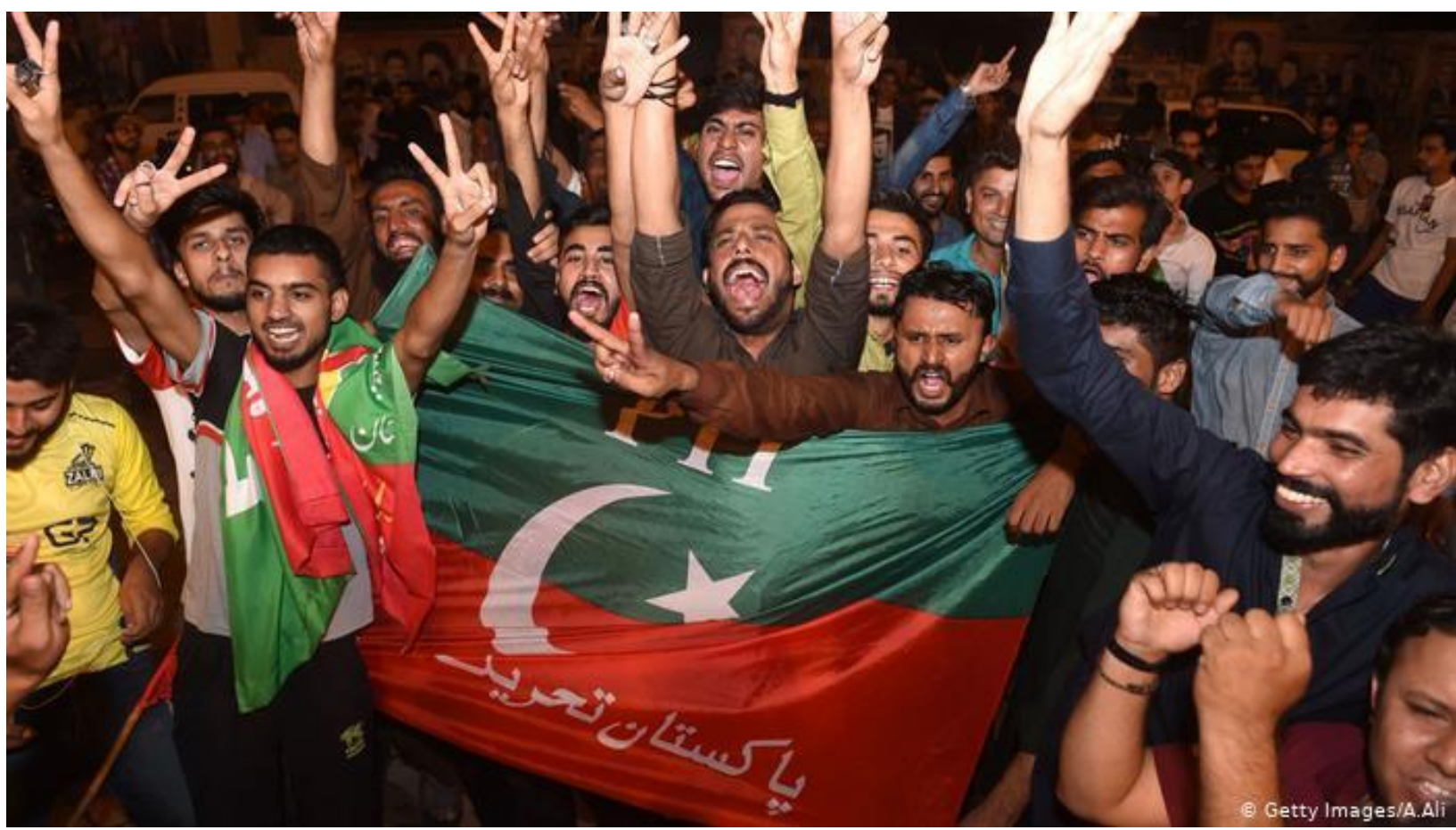

Figure 6: Ruling party's celebrations of senate elections

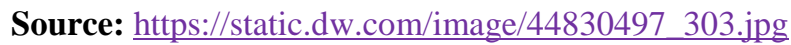

\section{CONCLUSION}

The researchers investigate and explore the reasons behind the spread of COVID19 during the second and third waves due to the violations of SOPs set by the government regarding keeping the masses safe from COVID-19, especially during the political processions Gilgit Baltistan and Senate elections. The elections were held just before the second and third waves of COVID-19. Pakistani Premier and his cabinet ministers did an excellent job during the first wave of COVID-19 through smart lockdown and made persuasive speeches to create awareness about the pandemic. Premier remarkably persuaded the people by employing persuasive strategies. He urged the people that only the precautions could keep them safe and sound from this harmful virus. However, after performing well during the first wave, his party violated the rules and precautions severely. While, other likewise nations like Malaysia, UAE, Saudi Arabia, Indonesia, or Brazil responded well by postponing all activities. They closed the education sectors, trade markets, and religious prayers (the Saudi government even locked Makkah and Medina for Hajj and Umrah performances for the first time in history for the Pilgrims).

Further, the opposition parties also allied with the Pakistan Democratic Movement and started their political processional campaigns. Both the opposition and the ruling government party (PTI) gathered the people at public places without COVID-19 SOPs. The COVID-19 cases increased hurriedly after these campaigns from 300 to 6000 daily patients.

\section{LIMITATION AND STUDY FORWARD}

The present study was delimited to the violations of SOPs that the government of Pakistan settled during the second and third waves of COVID-19 in Pakistan. The researcher only focused on the two elections campaigns, provincial in Gilgit Baltistan and senate elections, respectively, which were held just before the second and third waves of COVID. Any other political or non-political events and violations of SOPs are excluded from this study. Future researchers may conduct research focusing on the other factors involved in the spike of COVID-19.

\section{AUTHORS CONTRIBUTION}

Hanan Afzal: The first author of the study initiated the research idea and completed it with the help of others working on each part of the study.

Masroor Sibtain: The second author of the research extracted and modified the theoretical framework from his previous research and finally employed it in the present study. Moreover, he proofread and stylized the paper for publication.

Zafar Iqbal: The third author of the research collected the data and scrutinized it for the analysis.

Hina Saleem: The fourth author of the research worked on the analysis with the first author. 


\section{REFERENCES}

1. Ahmad, E., \& Mohammed, A. (2012). Pakistan, the United States, and the IMF: Great game or a curious case of Dutch Disease without the oil?. Asia Research Center Working paper: 1-21.

2. Alimolaie, A. (2020). A Review of Coronavirus Disease-2019 (COVID-19). Iranian Journal of Biology, 3(6), 152-157.

3. Ashfaq, M. and Bashir, M. (2021). Pakistan: making a "COVID budget" in a struggling economy. Journal of Public Budgeting, Accounting \& Financial Management, 33(1), 69-77. https://doi.org/10.1108/JPBAFM-072020-0118

4. Begum, G. (2015). Critical discourse analysis of the protesters' language. Language in India, 15(3), 85-95.

5. Bughio, F. A. (2014). Critical analysis of political discourse: A study of Benazir Bhutto's last speech. Balochistan Journal of Linguistics, 2, 79-95.

6. Díaz, D. P., Kawada, F. H., Chávez, R. C., \& Monzón, N. S. (2019). Political Discourse Analysis: Conceptual and analytical tools for the critical study of educational policies in times of global reform. Education Policy Analysis Archives, 27(47), 1-33. https://doi.org/10.14507/epaa.27.4269

7. Dunmire, P. L. (2012), Political Discourse Analysis: Exploring the Language of Politics and the Politics of Language. Language and Linguistics Compass, 6, 735-751. https://doi.org/10.1002/lnc3.365

8. Fischer, F., \& Gottweis, H. (eds.). (2012). The argumentative turn revisited: Public policy as communicative practice. Durham, NC; Duke University Press. https://doi.org/10.1215/9780822395362

9. Siddique, A. (2020, December 7). Pakistan's Politicians Playing A 'Dangerous' Game With COVID. Gadara. Retrieved from https://gandhara.rferl.org/ on June 2, 2021.

10. Gul, A. (2020, April 12). Pakistan PM Seeks Debt Relief for Developing Nations tonight, virus. VOA News. Retrieved from https://www.voanews.com/science-health/coronavirus-outbreak/Pakistan-pm-seeks-debt-reliefdeveloping-nations-fight-virus

11. COVID-19: 20,000 quarantined in Pakistan after gathering (2020, April 5). Gulf News. Retrieved from https://gulfnews.com/world/asia/pakistan/covid-19-20000-quarantined-in-pakistan-after-gathering-1.15861008 $\underline{53639}$

12. Hani, C., Trieu, N.H., Saab, I., Dangeard, S., Bennani, S., Chassagnon, G. and Revel, M.-P. (2020). COVID-19 pneumonia: A review of typical C.T. findings and differential diagnosis. Diagnostic and Interventional Imaging, 101(5), 263-268. https://doi.org/10.1016/j.diii.2020.03.014

13. Hassan, A. (2018). Language, Media, and Ideology: Critical Discourse Analysis of Pakistani News Bulletin Headlines and Its Impact on Viewers. SAGE Open. https://doi.org/10.1177/2158244018792612

14. Higgin, C. \& Walker, R. (2012). Ethos, Logos, Pathos: Strategies of Persuasion in Social/Environmental Reports. Accounting Forum, 36(3), 194-208. https://doi.org/10.1016/j.accfor.2012.02.003

15. Inayat, N. (2020, December 3). Pakistan is playing pandemic politics — Imran Khan's good jalsa vs. opposition's bad jalsa. ThePrint. https://theprint.in/opinion/letter-from-pakistan/pakistan-is-playing-pandemicpolitics-imran-khans-good-jalsa-vs-oppositions-bad-jalsa/556398/

16. Iqbal, M. A., \& Younas, M. Z. (2021). Public knowledge, attitudes, and practices towards COVID-19 in Pakistan: A cross-sectional study. Children and Youth Services Review, 120, 105784. https://doi.org/10.1016/j.childyouth.2020.105784

17. Iqbal, Z., Aslam, M. Z., Aslam, T., Ashraf, R., Kashif, M. \& Nasir, H. (2020). Persuasive Power Concerning COVID-19 Employed by Premier Imran Khan: A Socio-Political Discourse Analysis. Register Journal, 13(1), 208-230. https://doi.org/10.18326/rgt.v13i1.208-230

18. Iqbal, Z., Khan, I., Shahzad, K. \& Aslam, T. (2020b). Persuasive Political Power Employed by Premier Imran Khan to Deform Identity: A Political Discourse, Journal for the Study of English Linguistics, 9(1), 12-24. https://doi.org/10.5296/jsel.v9i1.18005

19. Khan, F., Saeed, A., \& Ali, S. (2020). Modelling and forecasting new cases, deaths and recover cases of COVID-19 by using Vector Autoregressive model in Pakistan. Chaos, Solitons \& Fractals, 140, 110189. https://doi.org/10.1016/j.chaos.2020.110189

20. Kirvalidze, N. and Samnidize, N. (2016). Political discourse as a Subject of Interdisciplinary Studies. Journal of Teaching and Education, 5(1), 161-170.

21. Ksiazek, T. G., Erdman, D., Goldsmith, C. S., Zaki, S. R., Peret, T., Emery, S., ... \& Rollin, P. E. (2003). A novel coronavirus associated with severe acute respiratory syndrome. New England journal of medicine, 348(20), 1953-1966. https://doi.org/10.1056/NEJMoa030781

22. Latif, E. A. (2016). Analysing Political Speeches: Rhetoric, Discourse and Metaphor. Metaphor and Symbol, 31(4), 250-252. https://doi.org/10.1080/10926488.2016.1223462

23. Li, Q., Guan, X., Wu, P. et al. (2020). Early Transmission Dynamics in Wuhan, China, of Novel CoronavirusInfected Pneumonia. The New England Journal of Medicine, 382(13), 1199-1207. https://doi.org/10.1056/NEJMoa2001316

24. Malay, D. S. (2020). COVID-19, pandemic, and social distancing. The Journal of Foot and Ankle Surgery, 59(3), 447. https://doi.org/10.1053/j.jfas.2020.03.010 
25. Martin, J. N., \& Nakayama, T. K. (2010). Language and intercultural communication: Intercultural communication in contexts. New York, NY: McGraw- Hill.

26. Nagri, J. (2020, December 3). Imran slams PDM rallies amid a spike in Covid cases. DAWN. https://www.dawn.com/news/1593683/imran-slams-pdm-rallies-amid-spike-in-covid-cases

27. Naz, S., Alvi, S. D., \& Baseer, A. (2012). Political language of Benazir Bhutto: A transitivity analysis of her speech 'democratization in Pakistan.'. Interdisciplinary Journal of Contemporary Research in Business, 4(8), 125-141.

28. Norali, N., \& Rezaei, S. (2016). Language and power: The use of persuasive techniques in Iran and U.S. President Speeches. Journal of Language Teaching and Research, 7(6), 1203-1209. https://doi.org/10.17507/jltr.0706.19

29. Ogen, Y. (2020). Assessing nitrogen dioxide (NO2) levels as a contributing factor to the coronavirus (COVID19) fatality rate. Science of The Total Environment, 138605. https://doi.org/10.1016/j.scitotenv.2020.138605

30. Rahman, M. M., Talukder, A., Chowdhury, M. M. H., Talukder, R. \& Akter, R. (2021). Coronaviruses in wild birds - A potential and suitable vector for global distribution. Vet Med Sci,7, 264- 272. https://doi.org/10.1002/vms3.360

31. Raza, S. I. (2020, November 30). Opposition main hurdle to tackling virus spread, says Imran. DAWN. Retrieved from https://www.dawn.com/news/1593164

32. Rogers, R. \& Schaenen, I. (2014). Critical Discourse Analysis, in Literacy Education: A Review of the Literature. Reading Research Quarterly, 49(1), 121-143. https://doi.org/10.1002/rrq.61

33. Saeed, U., Aslam, M. Z., Khan, A., Khan, M., Atiq, M. \& Bhatti, H. (2020). Rhetorical and Persuasive Strategies Employed by Imran Khan in his Victory Speech: A Socio-Political Discourse Analysis. International Journal of English Linguistics 10(2), 349-356. https://doi.org/10.5539/ijel.v10n2p349

34. Sahin, A. R., Erdogan, A., Agaoglu, P. M., Dineri, Y., Cakirci, A. Y., Senel, M. E., ... \& Tasdogan, A. M. (2020). 2019 novel coronavirus (COVID-19) outbreak: a review of the current literature. EJMO, 4(1), 1-7. https://doi.org/10.14744/ejmo.2020.12220

35. Sarfo, E. \& Krampa, A. E. (2013). Language at War: A Critical Discourse Analysis of Speeches of Bush and Obama on Terrorism. International J. Soc. Sci. \& Education, 3(2), 378-390.

36. Shah, M. I. \& Noreen, A. (2018). A Critical Discourse Analysis of Prime Minister of Pakistan Imran Khan's First Public Address. Public Policy and Administration Research, 8(9), 1-6.

37. Shahzadi, S. (2018). Critical Discourse Analysis of Tahir-ul-Qadri and Imran Khan's Dharna 2014 Speeches: A Comparative Analysis (Doctoral dissertation). COMSATS University Islamabad, (Lahore Campus).

38. Sharififar, M. \& Rahimi, E. (2015). Critical Discourse Analysis of Political Speeches: A Case Study of Obama's and Rouhani's Speeches at U.N. Theory and Practice in Language Studies, 5(2), 343-349. https://doi.org/10.17507/tpls.0502.14

39. Ting, S. (2018). Ethos, Logos, and Pathos in University Students' Informal Requests. Gema Online Journal of Language Studies, 18(1), 234-251. https://doi.org/10.17576/gema-2018-1801-14

40. van Dijk, T. A. (2005). Contextual knowledge management in discourse production. In Wodak, R. \& Chilton, P.A New Agenda in (Critical) Discourse Analysis: Theory, methodology and interdisciplinarity, 13, 71-100. https://doi.org/10.1075/dapsac.13.07dij

41. van Dijk, T. A. (2000). Ideology: A multidisciplinary approach. London: SAGE Publications Ltd.

42. van Dijk, T. A. (1997b). What is political discourse analysis? In Blommaert, J. and Bulcaen, C. (eds) Political Linguistics. Amsterdam: Benjamins, 11-52. https://doi.org/10.1075/bj1.11.03dij

43. van Dijk, T. A. (2006). Discourse and manipulation. Discourse \& Society, 17(3), 359-383. https://doi.org/10.1177/0957926506060250

44. Vulchanova, M., Vulchanov, V., Fritz, I. and Milburn, E. A. (2019). Language and perception: Introduction to the Special Issue "Speakers and Listeners in the Visual World." Journal of Cultural Cognitive Science, 3, 103112. https://doi.org/10.1007/s41809-019-00047-z

45. Wang, Y., \& Liu, H. (2018). Is Trump always rambling like a fourth-grade student? An analysis of stylistic features of Donald Trump's political discourse during the 2016 election. Discourse \& Society, 29(3), 299-323. https://doi.org/10.1177/0957926517734659

46. WMHC (2020). Wuhan Municipal Health and Health Commission's Briefing on the Current Pneumonia Epidemic Situation in Our City. Retrieve from http://wjw.wuhan.gov.cn/front/web/showDetail/2019123108989 on April 28, 2021.

47. Wodak, R. \& Chilton, P. (2005). A New Agenda in (Critical) Discourse Analysis: Theory, methodology and interdisciplinarity. John Benjamins Publishing Company. https://doi.org/10.1075/dapsac.13

48. Wodak, R. (2011). The discourse of politics in action: Politics as usual ( $2^{\text {nd }}$ revised edition). London, UK: Palgrave.

49. World Health Organization (WHO) (2020a). Novel Coronavirus-China: Confirmed CasesOver Time. Retrieved from https://covid19. who.int/region/wpro/country/cn on May 11, 2021.

50. World Health Organization (WHO) (2020). Coronavirus disease (COVID-19) Pandemic. Retrieved from https://www.who.int/emergencies/diseases/novel-coronavirus-2019 on May 17, 2021. 
51. World Health Organization (WHO) (2020b). Coronavirus disease (COVID-19) advice for the public. Retrieved from https://www.who.int/emergencies/diseases/novel-coronavirus-2019/advice-for-public on May 14, 2021.

52. Wu, F., Zhao, S., Yu, B. et al. (2020). A new coronavirus associated with human respiratory disease in China. Nature, 579, 265-269. https://doi.org/10.1038/s41586-020-2008-3

53. Xie, Q. (2018). Critical Discourse Analysis of News Discourse. Theory and Practice in Language Studies, 8(4), 399-403. https://doi.org/10.17507/tpls.0804.06

54. Zhao, J., Liao, X., Wang, H., Wei, L., Xing, M., Liu, L., \& Zhang, Z. (2020). Early virus clearance and delayed antibody response in a case of coronavirus disease 2019 (COVID-19) with a history of coinfection with human immunodeficiency virus type 1 and hepatitis C virus. Clinical Infectious Diseases, 71(16), 2233-2235. https://doi.org/10.1093/cid/ciaa408

55. Zhuang, Q., Liu, S., Zhang, X., Jiang, W., Wang, K., Wang, S., ... \& Chen, J. (2020). Surveillance and taxonomic analysis of the coronavirus dominant in pigeons in China. Transboundary and Emerging Diseases, 67(5), 1981-1990. https://doi.org/10.1111/tbed.13541 